\title{
Toxicity of the Bt Protein Cry1Ac Expressed in Leaves of the Event of Transgenic Soybean Released in Paraguay Against Spodoptera cosmioides
}

\author{
Cinthia Sosa ${ }^{1}$, Victor Gómez ${ }^{1}$, Maria Ramírez ${ }^{1}$, Edgar Gaona ${ }^{1} \&$ Magin Gamarra $^{1}$ \\ ${ }^{1}$ Plant Protection Department, Faculty of Agrarian Sciences, National University of Asunción, San Lorenzo, \\ Paraguay \\ Correspondence: Victor Gómez, Plant Protection Department, Faculty of Agrarian Sciences (FCA), National \\ University of Asunción (UNA), Route II Mcal, Estigarribia Km 10.5, University Campus, San Lorenzo, \\ Paraguay. E-mail: victor.gomez@agr.una.py
}

Received: September 13, 2020

Accepted: October 31, 2020

Online Published: November 15, 2020

doi:10.5539/jas.v12n12p107

URL: https://doi.org/10.5539/jas.v12n12p107

\begin{abstract}
Spodoptera cosmioides Walk (Lepidoptera: Noctuidae) is a polyphagous species, considered a secondary pest in soybean crop. The Intacta soybean (Bt soybean) event was released in Paraguay with Bt proteins which are supposed to be toxic for caterpillars. However, the effects of these proteins in the Spodoptera cosmioides biology still uncertainty. This study evaluated the biological activity of Bt soybean in $S$. cosmioides that were fed on Bt and non-Bt soybean leaves under laboratory conditions. The experiment was carried out at the Laboratory of Entomology; temperature $26 \pm 2{ }^{\circ} \mathrm{C}$; relative humidity: $60 \pm 10 \%$; photoperiod: $14: 00 \mathrm{~h}$ where 150 neonate larvae were used per treatment. The period and viability of each stage, the mortality of larval, number of eggs and neonate per couple, and the period of larvae to adult were the assessed variables. Higher mortality was observed in larvae fed with intact soybeans, but without statistical differences with non-Bt soybeans. For larval survival, period, number and total period, no statistical differences were verified. Higher percentage of fertility was observed in soybeans non-Bt but no statistical differences.
\end{abstract}

Keywords: genetically modified soybean, biology, pest, Spodoptera cosmioides

\section{Introduction}

In Paraguay, as well as the neighboring countries Brazil and Argentina, a widely spread soybean production system is the high-intensity no-till agriculture. This production system constitutes one of the economic stability piles because it successfully generates strong foreign exchange earnings through commodity exports. Recently, the soybean cropping surface registered for the 2018-2019 campaign, was over 3.5 million hectares, with a yield of 2,401 kg ha ${ }^{-1}$ (Capeco, 2020). The adoption of transgenic crops has been dramatically increasing in Paraguay; already by 2008 , the area of RR soybean represented $90 \%$ of Paraguayan production and the remaining $10 \%$ to conventional varieties. In 2015, the planting of soybean varieties was approved with a new event in Paraguay, the Bt soybean (soja Intacta), which besides being resistant to the herbicide glyphosate, contains the Bacillus thuringiensis (Bt) Cryl Ac gene for controlling some caterpillars of the Order Lepidoptera (Senave, 2020).

According to the Paraguayan Association of Plant Breeders, the currently coverage percentage of Bt soybean is approximately $40 \%$. Regarding the soybean pests, it presents a diversity of pests that constitute production limitations; the frequent species in this crop are Anticarsia gemmatalis, Pseudoplusia includes, Spodoptera eridania, Heliothis sp., Helicoverpa spp., Rachiplusia nu. Through every plant developing stages, from the vegetative to the reproductive stages, the occurrence of these pests can take place (Gomez et al., 2015).

In recent years, the occurrence of caterpillars of the Spodoptera genus has been increasing in soybean cultivation (Gómez et al. 2009). Altogether Spodotera eridania, and S. cosmioides, known as black caterpillars, joined the group that damages soybean leaves and pods. S. cosmioides feed on leaves from the edge to the inside, or makes holes, disregarding the thicker ribs. In reproductive stages of cultivation, the larvae feed on the pods, these being preferred over the leaves in the most developed larvae (last instars). The slow development of the last-instars larvae leads to greater consumption; staying longer in the same feeding place. Considering the potential for foliar consumption among different lepidopteran pests in soybean, it was verified that $S$. cosmioides can consume 
twice the leaf area than A. gemmatalis, Chrysodeixis (Pseudoplusia) includens, and S. frugiperda. Rainy climates and high temperatures favor their population outbreaks (Igarzabal \& Galvez, 2014). Specht et al., 2017 in a study on the abundance and species richness of owlet moths reported that considering all species together, individuals of Spodoptera species represented $4.2 \%$ of all larvae found on non-Bt soybeans, while their representation on Bt soybeans was $16.3 \%$. Among these $16 \%$ larvae abundance, the Bt soybean technology protects against the following so-called secondary pests that affect soybean cultivation: Rachiplusia nu, Chrysodeixis (Pseudoplusia) includens, A. gemmatalis and Crocidosema aporema and others of secondary importance such as Helicoverpa gelotopoeon, Achyra bifidalis, Heliothis virescens (Bortolotto et al., 2014), Spilosoma virginica and Colias lesbia. Regarding Spodoptera frugiperda, Elasmopalpus lignosellus and Helicoverpa zea, Bt soybean would register a partial control (Massoni et al., 2015). Several studies already reported the low efficacy of Bt Cry1Ac soybeans in the Spodoptera complex; Yu et al. (2013) mentioned under control of S. exigua, S. litura and A. ypsilon in studies of soybean Bt (Cry1 Ac). Silva (2013) studied the effect of soybean Bt and non-Bt plants on the biological aspects of $S$. cosmioides, where itdid not obtain significant differences in the biological aspects of the insect, such as viability, the period of the larval phase, the prepupal phase, fertility, and longevity. Bernardi et al. (2014) verified the low susceptibility of $S$. cosmioides, S. eridania, and S. frugiperda. Silva et al. (2016) mentioned that there was no effect on the development and reproduction of $S$. cosmioides fed on soybean leaves. Bt. Silva et al. (2016) in studies of effects on the biology of insect pests did not observe adverse effects on the development and reproduction of $S$. cosmioides. Similar studies within the same genus; Liu et al. (2018) mentioned that $S$. litura and $S$. frugiperda; belonging to the same genus; however, $S$. litura is tolerant to Cry1 Ac, while S. frugiperda is susceptible. Murua et al. (2018) reported that $S$. eridania and S. cosmioides were not susceptible to Cry1 Ac protein in soybean MON 87701-2 $\times$ MON 89788-1 in greenhouse evaluations. Rabelo et al. (2020) indicateed low susceptibility to Cry1 AC and Cry1F toxins for Spodoptera eridania. Although in recent publications, Machado et al. (2020) mentioned an important suppression Spodoptera cosmioides with the Bt technology and the cry $1 \mathrm{Ac} / \mathrm{Cry} 1 \mathrm{~F}$ genes of soybean.

Bt soybean $(\mathrm{Cry} 1 \mathrm{Ac})$ is a paramount solution as part of caterpillar control, however, with an intensive adoption due to reliance, it leaves an important window without chemical control to the Spodoptera complex, especially $S$. cosmioides, $S$. eridania, and $S$. frugiperda that could generate important impacts in the medium term. Carrying out investigations to verify the technology control levels over these pests at regional levels is the priority to optimize integrated pest management. In this context, studies were carried out in Paraguay to evaluate the Bt soybean event (Cry $1 \mathrm{Ac}$ ) toxicity on the $S$. cosmioides biology. The $\mathrm{Bt}$ toxin is expected to have some effect on the biology of this species.

\section{Methods}

\subsection{Location and Establishment of the Study}

Larvae of $S$. cosmioides were collected manually from an experimental soybean crop in the University campus in

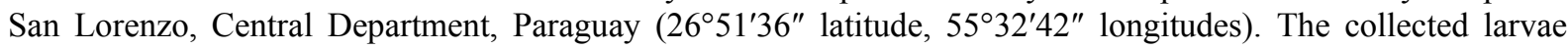
were placed in containers with an artificial diet in the field (Parra, 2001), then, they were transferred to the entomologic laboratory. There was a time window of 48 hours between collecting in the field and transferring to the laboratory. Once in the laboratory, the larvae were transferred again to another $50 \mathrm{ml}$ plastic container with the artificial diet. The larvae were under laboratory conditions of temperature $25 \pm 5{ }^{\circ} \mathrm{C}$, and $\mathrm{HR} 60 \pm 10 \%$, and photophase of 14:10 (L:D), until the pupal stage. The pupae were removed and disinfected carefully with $0.2 \%$ sodium hypochlorite in distilled water, then, they were placed on moisture filter paper in plastic dishes covered with $250 \mathrm{~cm}^{3}$ clear glasses. The emerged adults were transferred in mating cages (white PVC tubes $24 \mathrm{~cm}$ high and $14.5 \mathrm{~cm}$ in diameter) covered internally with white paper as an oviposition substrate. The cages were placed in plastic plates on filter paper and covered at the top with tulle-like fabric, to allow the cage aeration. Adults were fed with a $10 \%$ solution of water and honey, provided in containers of $1.5 \mathrm{~cm}$ in length and $2 \mathrm{~cm}$ in diameter full with cotton. Once the oviposition phase started, the internal white paper was removed and cut carefully in pieces around the eggs. This process was undertaking every 48 hours. The eggs were placed in $50 \mathrm{ml}$ plastic cups with a rounded piece of moistened filter paper on the lid to generate an appropriate humid chamber for the eggs. They were incubated (Temperature $24 \pm 2{ }^{\circ} \mathrm{C}$; photophase $14 \mathrm{~h}$ ) until hatching. The first generation hatched larva of laboratory (F1) was divided into two groups; one group was used for the experiment (hatched larvae with a maximum of $24 \mathrm{~h}$ of age) and the other group was used for the maintenance of the laboratory population. 


\subsection{Obtaining Vegetable Material}

The Intacta soybean expresses the Cry1 Ac protein and the soybean of the S909 RR variety (non-Bt) were planted in greenhouse in November. The leaves of these Bt and non-Bt soybeans were the plant part used for the experiment.

\subsection{Application of Treatments-Determination of Mortality}

Once the first generation was obtained; 150 neonatal larvae (maximum 24 hours old, considering 150 replications) were transferred carefully with a fine-bristled brush in plastic cups (one larvae each) containing soybean leaves (state R1 to R5). The leaves were previously washed with $0.2 \%$ sodium hypochlorite and rinsed with distilled water. They were placed in the bottom of the plastic cups on a $\%$ agar solution, covered with filter paper, which help to keep a fresh leaf. Initially, the leaves were changed in a two to three days basis; then in a daily basis, according to the larvae needs. Regarding feces, food remains, and dead larvae, they were immediately cleaned to avoid laboratory facilities contamination. The mortality percentage of $S$. cosmiodes larvae was determined by comparing the number of larvae that did not complete their cycle over the total number of studied larvae.

\subsection{Determination of the Larval and Pupal Stage Period}

Daily observations were required to verify larval mortality. For the larval phase period, those individuals which successfully went through the pre-pupae to pupae stages were considered. In the pre-pupal stage, the manipulation of the larvae was carried out carefully for not stressing them in these very sensible stages. After 24 hours from the metamorphosis to the pupal stage, the pupae were measured, weighed, and sexed, then they were washed with a $0.2 \%$ sodium hypochlorite solution $(\mathrm{NaClO})$ and rinsed with distilled water. Finally, they were placed on trays with a damp filter paper and the pupae were covered with $5 \mathrm{~cm} 3$ plastic cups previously labeled for identification. The filter paper had been moistening with distilled water every day.

\subsection{Egg Fecundity and Fertility}

Twenty coupled adults (20) were selected from the emerged adults; the remaining adults were placed individually, all in the mating PVC cages, and fed with $10 \%$ honey until death.

The twenty coupled adults were selected for the parameters assessment. The parameters evaluated in this phase were the number of eggs per female (fertility) and their fertility (viability), number of postures, and the longevity (days) of the adults.

The formula used for fertility (García and Iannacone, 2011):

$$
\text { Fecundity }=\left(\mathrm{N}^{\circ} \mathrm{HV}\right) /\left(\mathrm{N}^{\circ} \mathrm{Hvs}\right)
$$

Where, $\mathrm{N}^{\circ} \mathrm{HV}=$ Number of females; $\mathrm{N}^{\circ} \mathrm{Hvs}=$ Number of eggs laid.

The egg masses carefully removed and placed in plastic cups sterilized with alcohol, filter paper moistened with distilled water placed on the lid to maintain the humidity of the eggs.

Fertility or viability according to what is indicated by Hernández et al. (2010):

$$
\text { Fertility }=\mathrm{N}^{\circ} \mathrm{Hvs} /\left(\mathrm{N}^{\circ} \mathrm{N}\right)
$$

Where, $\mathrm{N}^{\circ} \mathrm{Hvs}=$ Number of eggs laid; $\mathrm{N}^{\circ} \mathrm{N}=$ Number of neonates.

\subsection{Determination of Period (Days) of the Plague Cycle}

The surviving insects that completed the entire larva to adult phases of individuals observed by treatment were considered.

\subsection{Variables}

The variables considered are the percentage of insect mortality from each treatment. Period of larval, prepupal, and pupal phase, (days). Egg fecundity and fertility, number of postures, the longevity of adults, and the total cycle of the pest (days).

\subsection{Statistical Analysis}

An analysis of variance (ANOVA) was performed for the experiment data. The means of each parameter were compared for significant differences by Student's protected least significant difference test at $(\mathrm{p} \leq 0.05)$ was run using a statistical software INFOSTAT-2014 (Di Rienzo et al., 2014). 


\section{Results and Discussion}

\subsection{Mortality of S. cosmioides in Soybean Bt}

The sum of larvae mortality observed in Spodoptera cosmioides larvae fed Bt Cry1Ac soybean does not present statistical differences $(p=0.2451)$; compared to RR non-Bt. soybeans (Table 1). Furthermore, studies from different latitudes are highlighting the low efficacy of Bt Cry1Ac soybeans on the Spodoptera complex; Yu et al. (2013) mention limited action of Bt Cry1 Ac soybean on S. exigua, S. litura, and Agrotis ypsilon. Bernardi et al (2014) mention the low mortality of $S$. cosmioides and $S$. eridania exposed to Cry1 Ac purified proteins. Silva et al. (2016) that studying the effect of $\mathrm{Bt}$ and non-Bt soybean plants on biological aspects of $S$. cosmioides mention an 83\% survival in larvae fed with Bt CrylAc soybeans. Murua et al. (2018) mention that comparative studies of defoliation of Bt CrylAc soybean and non-Bt soybean from $S$. cosmioides show similar values despite the statistical significance. In Paraguay considering this study, the results are similar to the above mentioned authors; the suppression control verified in this investigation considered the Cry 1Ac event as ineffective for this specific pest. This concern about the inefficient control against the $S$. cosmioides put into perspective the whole scheme control that is using in Paraguay nowadays. Since the adoption of this Bt biotechnology still increasing and the behavioral damages for the spodoptera caterpillar complex is very dynamic, the management pest control for the soybean crop must be reevaluated eventually. At some point this pest management could collapse letting the chance for Spodoptera cosmioides becoming a more danger pest for the soybean crop, changing its status from secondary pest, to main pest of soybean.

Table 1. Mortality (\%) in each instar and of the larval phase of S. cosmioides Walk (Lepidoptera: Noctuidae) fed with leaves of Bt soybean (M6410ipro) and Non-Bt soybean (S909) in controlled conditions. Temperature $26 \pm 2$ ${ }^{\circ} \mathrm{C}$; RH: $60 \pm 10 \%$; Photoperiod: 14:00 Hs

\begin{tabular}{lllllllll}
\hline \multirow{2}{*}{ Treatment } & \multicolumn{9}{c}{ Instars } & \multicolumn{1}{c}{ Sum of larvae } \\
\cline { 2 - 8 } & $\mathbf{1}^{\mathbf{0}}$ & $\mathbf{2}^{\mathbf{0}}$ & $\mathbf{3}^{\mathbf{0}}$ & $\mathbf{4}^{\mathbf{0}}$ & $\mathbf{5}^{\mathbf{0}}$ & $\mathbf{6}^{\mathbf{0}}$ & $\mathbf{7}^{\mathbf{0}}$ & mortality (\%) \\
\hline Soybean Bt Cry1Ac & 2.0 & 9.3 & 12.0 & 3.3 & 0.0 & 0.0 & 0.0 & $26.6 \mathrm{a}$ \\
Non-Bt soybean & 0.6 & 7.3 & 0.6 & 0.0 & 0.0 & 0.0 & 0.0 & $8.5 \mathrm{a}$ \\
\hline
\end{tabular}

Note. Means in columns with equal letters are statistically similar at a significance level of $5 \%(\mathrm{p} \leq 0.05)$. Student test $(\mathrm{n}=150)$.

\subsection{Period of Each Instar, the Number of Instars, and the Period of the Larval Period}

Considering the surviving larvae, the period of each instar, the number of instars, and the total period (Table 2); no significant differences were registered between the treatments in the first, $3 r d(p=0.0768)$ and 7 th instar $(p=$ $0.2016)$. However, there are differences in the $2 \mathrm{nd}(\mathrm{p}=0.0494)$, 4th $(\mathrm{p}=0.0389), 5$ th $(\mathrm{p}=0.004)$ and 6 th $(\mathrm{p}=$ $0.0044)$ instars. During the total larval stage, the period was similar between the treatments $(p=0.8395)$. Bernardi et al. (2014) and Silva (2016) did not observe significant differences in the period of the larval stage; studying the biology of $S$. cosmioides in soybean Bt and non-Bt.

Table 2. Period (in Days) of each instar, the number of instars, and period of the larval period of $S$. cosmioides Walk (Lepidoptera: Noctuidae) fed with leaves of Bt soybean (M6410ipro) and Non-Bt soybean (S909) in controlled conditions. Temperature $26 \pm 2{ }^{\circ} \mathrm{C}$; RH: $60 \pm 10 \%$; Photoperiod: $14: 00 \mathrm{Hs}$

\begin{tabular}{lllllllll}
\hline \multirow{2}{*}{ Treatment } & \multicolumn{9}{c}{ Instars } & \multicolumn{1}{c}{ Total Larvae Phase } \\
\cline { 2 - 8 } & $\mathbf{1}^{\mathbf{0}}$ & $\mathbf{2}^{\mathbf{0}}$ & $\mathbf{3}^{\mathbf{0}}$ & $\mathbf{4}^{\mathbf{0}}$ & $\mathbf{5}^{\mathbf{0}}$ & $\mathbf{6}^{\mathbf{0}}$ & $\mathbf{7}^{\mathbf{0}}$ & \multicolumn{1}{c}{ (Days) } \\
\hline Soybean Bt Cry1Ac & $2.15 \mathrm{a}$ & $2.33 \mathrm{a}$ & $2.06 \mathrm{a}$ & $2.34 \mathrm{a}$ & $2.80 \mathrm{a}$ & $4.53 \mathrm{a}$ & $7.74 \mathrm{a}$ & $23.9 \mathrm{a}$ \\
Non-Bt soybean & $2.06 \mathrm{a}$ & $2.59 \mathrm{~b}$ & $2.34 \mathrm{a}$ & $2.14 \mathrm{~b}$ & $3.15 \mathrm{~b}$ & $5.33 \mathrm{~b}$ & $8.02 \mathrm{a}$ & $25.6 \mathrm{a}$ \\
\hline CV $(\%)$ & 9.82 & 14.64 & 18.30 & 12.65 & 9.81 & 19.77 & 10.06 & 10.2 \\
\hline
\end{tabular}

Note. Means in columns with equal letters are statistically similar at a significance level of $5 \%(\mathrm{p} \leq 0.05)$. Student test $(\mathrm{n}=150)$.

\subsection{Fecundity, Neonates, and Fertility}

In observations of fecundity, neonates, and fertility (Table 3); despite not detecting significant differences between both treatments $(\mathrm{p}=0.5514 ; \mathrm{p}=0.4829 ; \mathrm{p}=0.0626)$, a higher percentage of viability or fertility in insects fed with 
RR non-Bt soybeans was observed; with a noticeable difference in this variable. The insects fed with soybean leaves with the BtCry1Ac protein presented lower egg viability, which is an indication of antibiosis caused by the presence of the Bt event. Similar results were obtained in Silva (2013) studies. In response to these results, field-level research related to population dynamics or growth of $S$. cosmioides in this variety should be intensified.

Table 3. Average fecundity, Neonates, and fertility (\%) of S. cosmioides Walk (Lepidoptera: Noctuidae) fed with leaves of Bt soybean (M6410ipro) and Non-Bt soybean (S909) in controlled conditions. Temperature $26 \pm 2{ }^{\circ} \mathrm{C}$; RH: $60 \pm 10 \%$; Photoperiod 14:00 Hs

\begin{tabular}{llll}
\hline Treatment & Fecundity & Neonates/Couples & Fertility \% \\
\hline Soybean Bt Cry1Ac & $796.47 \mathrm{a}$ & $335.68 \mathrm{a}$ & $46.74 \mathrm{a}$ \\
Non-Bt soybean & $704.11 \mathrm{a}$ & $403.44 \mathrm{a}$ & $61.17 \mathrm{a}$ \\
\hline CV (\%) & 62.13 & 78.81 & 42.44 \\
\hline
\end{tabular}

Note. Means in columns with equal letters are statistically similar at a significance level of $5 \%(\mathrm{p} \leq 0.05)$. Student test $(n=20)$.

\subsection{Period of Each Phase and the Larva to Adult Period}

There aren't statistical difference in the period of the larval stage $(\mathrm{p}=0.8394)$. The pre-pupa $(\mathrm{p}=0.1232)$, pupa $(\mathrm{p}=0.3256)$, and adult phases $(\mathrm{p}=0.2680)$ did not show differences between the treatments. In the cycle total period, the insects reared with Bt Cry1Ac soybean presented a shorter period than the insects fed with non-Bt soybeans, though without statistical differences $(\mathrm{p}=0.9360)$. Bavaresco et al. $(2003,2004)$ mention similar results; On the other hand, Silva et al (2011) in the larvae of $S$. cosmioides fed with soybean leaves obtained a period of the larva-adult period of 33.51 days.

Tabla 4. Average period (in days) of each phase and the larva to the adult period of S. cosmioides Walk (Lepidoptera: Noctuidae) fed with leaves of Bt soybean (M6410ipro) and Non-Bt soybean (S909) in controlled conditions. Temperature $26 \pm 2{ }^{\circ} \mathrm{C}$; RH: $60 \pm 10 \%$; Photoperiod 14:00 Hs

\begin{tabular}{llllll}
\hline Treatment & Larvae & Pre-pupa & Pupa & Adult & Period Larvae to Adult \\
\hline Soybean Bt Cry1Ac & $23.9 \mathrm{a}$ & $2.05 \mathrm{a}$ & $12.94 \mathrm{a}$ & $13.45 \mathrm{a}$ & $52.34 \mathrm{a}$ \\
Non-Bt soybean & $25.6 \mathrm{a}$ & $2.18 \mathrm{a}$ & $13.07 \mathrm{a}$ & $13.68 \mathrm{a}$ & $67.6 \mathrm{a}$ \\
\hline $\mathbf{C V}(\%)$ & 10.2 & 30.63 & 8.96 & 19.30 & 5.64 \\
\hline
\end{tabular}

Note. Means in columns with equal letters are statistically similar at a significance level of $5 \%(\mathrm{p} \leq 0.05)$. Student test $(\mathrm{n}=150)$.

Considering the results of this investigation; the degree of control of Spodoptera cosmioides with the use of soybeans with the Bt CrylAc event should be subject to more investigation; the laboratory results verify a low level of mortality of this insect. In this way and already mentioned above with the massive use of soybean technology Bt; there is a probability that the Spodoptera complex may become key pests in soybean cultivation. The suppression that it may be insufficient at the field level so should consider within the proper management of these pests.

\section{Conclusion}

Under the conditions where this experiment was carried out, the Bt Cry1Ac soybean presents slightly negative effects considering the mortality and fertility biological parameter of the surviving insects of Spodoptera cosmioides.

\section{References}

Babaresco, A., Garcia, M. S., Grutzmacher, A. D., Ringenberg, R., \& Foresti, J. (2004). Adequação de uma deita artificial para criação de Spodoptera cosmioides (Walk) (Lepidoptera: Noctuidae) em laboratório. Neotropical Entomology, 33. https://doi.org/10.1590/S1519-566X2004000200005

Bavaresco, A., Silveira, M., Dionei, A., Foresti, J., \& Ringenberg, R. (2003). Biologia comparada de Spodoptera cosmioides (Walk.) (Lepidoptera: Noctuidae) em cebola, mamona, soja e feijão. Ciência Rural, 33(6), 993-998. https://doi.org/10.1590/S0103-84782003000600001 
Bernardi, O., Sorgatto, R. J., Barbosa, A. D., Domingues, F., Dourado, P. M., Carvalho, R. A., ... Omoto, C. (2014). Low susceptibility of Spodoptera cosmioides, Spodoptera eridania and Spodoptera frugiperda (Lepidoptera: Noctuidae) to genetically-modified soybean expressing Cry1Ac protein. Crop Protection, 58, 33-40. https://doi.org/10.1016/j.cropro.2014.01.001

CAPECO (Cámara Paraguaya de Exportadores y Comercializadores de Cereales y Oleaginosas). (2020). Área de siembra, producción y rendimiento: Estadística soja. CAPECO, Paraguay. Retrieved from http://capeco.org. py/en/area-de-siembra-produccion-y-rendimiento

Di Rienzo, J. A., Casanoves, F., Balzarini, M. G., Gonzalez, L., Tablada, M., \& Robledo, C. W. (2014). InfoStat versión 2014. Grupo InfoStat, FCA, Universidad Nacional de Córdoba, Argentina. Retrieved from http://www.infostat.com.ar

García, J., \& Iannacone, J. (2011). Viabilidad de huevos y modelo de jaula para la cría artificial masiva de Anastrepha fraterculus (Diptera, Tephritidae). Revista de Sociedad Entomológica Argentina, 70(3-4): 267-276. https://www.redalyc.org/articulo.oa?id=322028524010

Gómez, V. A., Cabral, C., \& Ramirez, M. (2009). Aspectos biologicos de Spodoptera eridania (Lepidoptera: Noctuidae) criadas en diferentes tipos de dieta. San Lorenzo: INBIO.

Gómez, V., Ramirez, M., Arias, O., Gaona, E.,Ocampos, O., Flore, C., ... Escobeiro, S. (2015). Aspectos biológicos de plagas claves del cultivo de la soja en Paraguay. San Lorenzo, Paraguay: FCA-UNA/INBIO.

Hernandez, E., Rivera, P., Orozco-Davila, D., Salvador, M., \& Toledo, J. (2010). An artificial larval diet for rearing of Anastrepha striata (Diptera: Tephritidae). Florida Entomologist, 93(2), 167. https://doi.org/ 10.1653/024.093.0204

Igarzabal, D., \& Galvez, M. C. (2004). Características de Spodoptera cosmioides. Parana. INTA.

Liu, L., Chena, Z., Yanga, Y., Xiaob, Y., Liuc, C., Ma, Y., ... Liua, K. (2018). A single amino acid polymorphism in $\mathrm{ABCC} 2$ loop 1 is responsible for differential toxicity of Bacillus thuringiensis Cry1 Ac toxin in different Spodoptera (Noctuidae) species. Insect Biochemistry and Molecular Biology, 100, 59-65. https://doi.org/ 10.1016/j.ibmb.2018.06.004

Luz, P., Spechtb, A., Moraes, S., Malaquias, J., Otanásio, P., \& Diniz, I. (2018). Owlet moths (Lepidoptera: Noctuidea) associated with Bt and non-Bt soybean in the brazilian savanna. Brazilian Journal of Biology, 79(2), 248-256. https://doi.org/10.1590/1519-6984.179759

Machado, E., Rodrigues, G., Somavilla, J., Führ, F., Zago, S., Marques, L., ... Bernanrdi, O. (2020). Survival and development of Spodoptera eridania, Spodoptera cosmioides and Spodoptera albula (Lepidoptera: Noctuidae) on genetically-modified soybean expressing Cry1Ac and Cry1F proteins. Pest Management Science. https://doi.org/10.1002/ps.5955

Massoni, F. A., Trossero, M., \& Frana, J. (2015). Cultivos de soja Bt y convencional expuestos a poblaciones naturales de organismos plaga y benéficos. EEA.Rafaela: INTA.

Murúa, M. G., Vera, M., Herrero, M., Fogliata, S. V., \& Michel, A. (2018). Defoliation of Soybean Expressing Cry1 Ac by Lepidopteran Pests. Insects, 93(9),1-13. https://doi.org/10.3390/insects9030093

Parra, J. R. P. (2001). Técnicas de criação de insetos para programas de controle biológico. FEALQ, Piracicaba.

Rabelo, M., Matos, J., Santos-Amaya, O., França, J., Gonçalves, J., Moraes, S., ... Pereira, E. (2020). Bt-toxin susceptibility and hormesis-like response in the invasive southern armyworm (Spodoptera eridania). Crop Protection, 132. https://doi.org/10.1016/j.cropro.2020.105129

Senave (Servicio Nacional de Calidad y Sanidad Vegetal y de Semillas). (2020). Maíz. Listado de eventos con modificación genética liberados en el país. Asunción, PY. Retrieved from http://web.senave.gov.py:8081/ docs/Listado\%20de\%20eventos\%20liberados\%20comercialmente\%20en\%20el\%20pais-2019.pdf

Silva, D. M., Zimmermann, A. O., Bueno, A. F., \& Moscardi, F. (2011). Aspectos biologicos de Spodoptera cosmioides Walk. (Lepidoptera: Noctuidae) em diferentes plantas hospedeiras. Londrina, Parana: Embrapa Soja.

Silva, G. V., Bortolotto, O. C., Biato, R. R., Tonsic, D. H., Pomari, A. F., Yatie, A. M., \& Bueno, A. F. (2013). Biologia de Spodoptera cosmioides (Walker, 1858) (Lepidoptera: Noctuidae) em soja Bt e não-Bt. Londrina, Parana: Embrapa Soja. 
Silva, G., Bueno, B, Bortolotto, O., Santos, A., \& Pomari-Fernandes, A. (2016). Biological characteristics of black armyworm Spodoptera cosmioides on genetically modified soybean and corn crops that express insecticide Cry proteins. Revista Brasilera de Entomologia, 60, 255-259. https://doi.org/10.1016/j.rbe. 2016.04.005

Yu, H., Romeis, J., Li, Y., Li, X., \& Wu, K. (2013). Expression of Cry1Ac in transgenic Bt soybean lines and their efficiency in controlling lepidopteran pests. Pest Management Science, 69, 1326-1333. https://doi.org/ $10.1002 /$ ps.3508

\section{Copyrights}

Copyright for this article is retained by the author(s), with first publication rights granted to the journal.

This is an open-access article distributed under the terms and conditions of the Creative Commons Attribution license (http://creativecommons.org/licenses/by/4.0/). 